\title{
Sporophore morphology and development in the myxomycetes: a review
}

\section{Clark $\mathbf{J}^{1}$ and Haskins $\mathbf{E F}^{2}$}

${ }^{1}$ Department of Biology, University of Kentucky, Lexington, Kentucky 40506

${ }^{2}$ Department of Biology, University of Washington, Seattle, Washington 98195

Clark J, Haskins EF 2014 - Sporophore morphology and development in the myxomycetes: a review. Mycosphere 5(1), 153-170, Doi 10.5943/mycosphere/5/1/7

\begin{abstract}
Since the sporophores of the myxomycetes are the primary basis of taxonomy in the myxomycetes, an understanding of the development and range of variations of the various morphological structures is essential to constructing a valid system. A review of the morphology of the stipe, peridium, capillitium, and spores and their developmental aspects was undertaken and the resulting morphological hypotheses tested against recent advancements in DNA phylogeny, isozyme and DNA population, and genetic reproduction studies.
\end{abstract}

Key words - aethalium - epihypothallic - plasmodiocarp - slime-molds - sporangium - sporocarp - subhypothallic

\section{Introduction}

In the myxomycetes, the end point of the protoplasmic assimilative plasmodial stage is either the production of sporophores or a sclerotium. The sporophore is the site of the production of spores which serve as the major dispersal unit in the life cycle, and the sclerotium is a resistant stage that baring mechanical dislodgement remains in the original location until environmental conditions improve. The characteristics of the sporophore are also the primary basis of our current system of classification in the myxomycetes. Therefore, an understanding of the structure, development and variations of sporophore morphology is critical to a proper recognition of species and the construction of a reasonable taxonomic structure. However, one fact that should be stressed (Martin \& Alexopoulos 1969) is that, besides the normal small variations that occur in all species, in the myxomycetes larger variations can be produced by abnormal environmental conditions during sporulation. Sporulation characteristically requires approximately 24 hours for the completion of the larger sporophores, and if unusually cool, rainy or dry conditions are prevalent, relatively major morphological variations may occur; such as stipitate species lacking stipes, short stalked species producing long stalks, and lime deposits which may be absent or altered. This has led, in some cases, to a tendency to assign varietal, or even species, names to some of these variations due to a lack of understanding of the plasticity of morphological development in this group.

The basic outline for the microscopic study of myxomycete morphology was established by Rostafinski $(1873,1874,1875,1876)$ in his dissertation and Sluzowce Monografia (see Cooke 1877 for a English publication with an exact translation of the system); with the major divisions 
based on spore color (light vs. dark), presence or absence of capillitia, presence or absence of lime, and lime type (granular or crystalline). This outline was fleshed out and refined over time (deBary 1886, Lister \& Lister 1925) to produce the mature morphological concepts covered in "The Biology of the Myxomycetes" by Gray and Alexopoulos (1968). However, there have been some recent advances in morphological and taxonomic information (Eliasson 1977, Clark 2000, Schnittler \& Spiegel 2012) which, along with this earlier information, can now be tested against a fairly comprehensive DNA phylogeny (Fiore-Donno et al. 2005, 2008, 2009, 2010, 2011, 2012, 2013 Nandipati et al. 2012).

\section{General Morphology}

Under favorable conditions, which have been determined for only a relatively few species, the plasmodium of each species of myxomycete develops into the characteristic sporophore which is the basis of identification of that species. The first comprehensive examination of general sporocarp morphology was by Baker (1933) who produced numerous detailed line drawings derived from cross-section of sporocarps, which served as the basis for later works from the Iowa school. Since there is no agreement upon terminology for sporophore forms and structures, we will adopt, for the most part, that used by Gray and Alexopoulos (1968) with additions from Matsumoto (1999) and others. While sporophores can vary greatly in size and shape, they can be divided into a relatively few basis types: sporangial, plasmodiocarpous, pseudoaethalial, aethalial and exosporous. The first four types produce spores inside the sporophore (endosporous) and are usually designated as sporocarps. Excellent light and electron micrographs and descriptions of sporophores and their morphology have recently been published (Schnittler \& Spiegel 2012) in the "Syllabus of Plant Families", which individuals unfamiliar with the myxomycetes could find to be an additional useful source of information.

The sporangial type is generally a relatively small sporocarp, which is fairly constant in size and form for each particular species. Depending upon the species and its plasmodial type, one or many sporangia can be produced by each plasmodium. The sporocarp generally consists of two parts, the sporotheca and the stipe (Lado \& Pando 1997). The sporotheca is the spore containing part of the sporocarp and it consists of the peridium, capillitium, columella and spores, while the stipe, in the stipitate species, is the support and attachment part of the sporocarp consisting of the hypothallus, stalk, and columella. The hypothallus is the attachment region of the stipe which anchors the sporangium to the substrate, and it blends into the stalk region which apparently serves to raise the spore bearing sporotheca into turbulent air for better spore dispersal, while the columella is an extension of the stipe into the sporotheca. However, many sporangial species are sessile, in that the stipe is reduced and consist solely of the hypothallus. The sporotheca, which is present in all species, consist of many small spores enclosed by a peridium, which may be persistent or rapidly dehiscent at maturity. The spores are generally enmeshed in a characteristic capillitial system of threads, tubes, plates, etc. which function as a support for the spores during their release, however, in many species, a capillitium is greatly reduced or totally lacking. The plasmodiocarpous type of sporocarp is much like a sessile sporangium, but is usually larger and takes the form of a condensed plasmodium or a number of smaller sporangial-like sections, which in some species, such as Physarella oblonga, grade into sessile sporangia (Gray 1949). Plasmodiocarps are mostly sessile (rarely stipitate), but have a hypothallus, and the spore containing sporotheca has a peridium and usually a capillitial system. The aethalial type of sporocarp is generally a large structure which is considered to be evolutionarily derived from a mass of completely fused sporangia (Massee 1892, Lister \& Lister 1925, Baker 1933). The aethalia are always sessile with an anchoring hypothallus, and the sporocarp has a peridial cortex, which surrounds the spores and supporting network, that is generally present and consist of capillitia and or pseudocapillitia. Pseudocapillitia are membranous expansions or branching tubes which may represent the wall remnants of the fused sporangia, although it was pointed out by Baker (1933) that there is no evidence to support this assumption. The pseudoaethalial type of sporocarp is intermediate in form between sporangial and aethalial, in that it consists of a mass of closely 
compacted sporangia forming a single sporocarp in which the individual sporangia remain discernible (Baker 1933). The exosporous type, which produces individual spores on the surface of the sporophore, is found only in the genus Ceratiomyxa, and it differs considerably from the other types which are endosporous. In this type, the sporophore consists of a matrix of highly vacuolated amorphous material that forms simple pillar-like to coralloid structures upon which the individually stalked spores are borne.

\section{Taxonomy}

Since the current taxonomy of the myxomycetes is based upon sporophore morphology, any discussion of sporophore morphology and development automatically involves taxonomic considerations. The Myxomycetes are typically divided into six orders (Martin \& Alexopoulos 1969, Schnittler \& Spiegel 2012): Ceratiomyxales, Echinosteliales, Liceales, Trichiales, Stemonitales and Physarales. The Ceratiomyxales produce their spores on the exterior of the sporophore (exosporous), as opposed to the rest of the orders which produce their spores inside the sporotheca (endosporous), This considerable difference has initially caused most taxonomists to place Ceratiomyxa (the only exosporous genus) into a separate subclass Ceratiomyxomycetidae (Martin \& Alexopoulos 1969) or to place Ceratiomyxa with the Protostelia (Spiegel 1990), a possible sister group to the myxomycetes consisting of a number of species producing mostly single stalked exospores from amoebae or small plasmodia. However, recent DNA phylogenetic studies (Fiore-Donno et al. 2009) indicate that Ceratiomyxales is a sister group to the endosporous orders and is not closely related to most Protostelia which also appear to be polyphyletic (Shadwick et al. 2009). The Echinosteliales are defined by light, rarely dark colored spores produced in a minute sporocarp usually having a stipe, columella and capillitium. This small order has been considered to be either a specialized group derived from the Physarales (Collins 1979) or a basal group derived from the Protostelia (Spiegel 1990); however recent DNA studies (Fiore-Donno et al. $2005,2008,2012$ ) place this order as a basal sister group to the dark spored endosporous orders, but not apparently closely related to the Protostelia. The Liceales, characterized by light or dark colored spores and sporocarps which lack true capillitia, are considered to be a somewhat variable group composed of three rather different families; and so far the limited DNA information (FioreDonno et al. 2009, 2013) generally supports this conclusion. The Trichiales, with bright colored spores and sporocarps with usually abundant ornamented capillitia have long been considered to be a natural morphological group, and this grouping is also generally supported by DNA phylogeny (Fiore-Donno et al. 2009, 2013). These DNA studies also indicate that the Liceales and Trichiales form a distinct clade defined by the presence of light or bright colored spores as first proposed by Rostafinski (1874, 1875, 1876, see Cooke 1877 for an English version of Rostafinski's views). However, the separation of these two orders by the presence or absence of capillitia is challenged by the DNA evidence (Fiore-Donno et al. 2013). Stemonitales, which are dark spored and generally lack sporocarp lime, and Physarales, dark spored with sporocarpic lime deposits, are also morphologically distinct groups which are supported by DNA phylogeny (Fiore-Donno et al. 2005, 2009, Nandipati et al. 2012). However, this DNA evidence also indicates that these two orders are members of a dark spored clade, which contradicts evidence from sporocarp developmental studies (Ross 1973) which placed the Stemonitales in a separate subclass (Stemonitomycetidae) from the rest of the endosporous orders.

\section{Sporophore Development}

The development of the exosporous sporophore (Ceratiomyxomycetidae) appear to be distinct from that of the endosporous species in that it is much simpler and lacks many of the structures characteristic of the endosporic sporocarp (Myxogastromycetidae). In Ceratiomyxa fruticulosa, the plasmodium moves to the surface of its substrate to forms a matrix, consisting of highly vacuolated amorphous material that dries to form the basic structure of the sporophore, which is considered, by some, to be homologous to the hypothallus of other species. A thin film of 
protoplasm on the surface of the matrix then undergoes cleavage to produce uninucleate units, which develop into the stalked spores (Gilbert 1935).

Sporocarps appear to be of two basis developmental types in the endosporous species: the subhypothallic and epihypothallic types. This dichotomy has been used to separate the endosporous species (Ross 1973, Alexopoulos 1973) into two subclasses: Stemonitomycetidae (epihypothallic) and Myxogastromycetidae (subhypothallic); although Olive (1975) considered that too few species had been studied to conclude that there are only two developmental types present in the endosporous species. In the subhypothallic developmental type, as seen in several species of Physarum, Didymium, Cribraria and Arcyria (Guttes \& Rusch 1961, Lucus et al. 1968, Mims \& Rogers 1975), the plasmodium first masses on the substrate and then divides into separate primordial units that form the individual sporocarps. These primordia then form protoplasmic pillars which elongate with the bulk of the material migrating to the tip to form a globose head which will develop into the sporotheca, while the lower portion constricting to form the stipe. The stipe, in most species studies, consist of an outer layer derived from the thickened plasmodial membrane and tough fibrillar strands which form a tubular structure, and a granular inner core region of amorphous material and waste materials which fills this membrane and fiber tube. The hypothallus is simply the lower flared attachment region of the stipe, and it is continuous with the stalk region, while the columella is generally the upper flared and rounded region of the stipe which projects into the sporotheca and is closed off with peridial-like material (Weldon 1955). The sporotheca is derived from the globose protoplasmic region of the pillars and it is surrounded by a peridium that is derived from the plasmodial membrane and condensed protoplasm which forms a generally tough non-cellular membranous covering. The remaining protoplasm, inside the peridium, then forms the capillitium by secreting material into a network of membranous interconnected tubes, and spores by cleaving the remaining protoplasm into uninucleate units with the secretion of wall materials around them.

In the epihypothallic developmental type, as seen in several Stemonitis, Comatricha, and Lamproderma species (Jahn 1931, Gray 1937, Ross 1957, Godwin 1961), the plasmodium first condenses into a pre-sporangial mass which divides into the separate primordial units that form the individual sporangia. After each primordium secretes a hypothallus onto the substrate, it then forms a stalk by secreting a tube composed of fibrillar material by adding to the hypothallus. As the stalk is elongated, by intraprotoplasmic secretion of material to the growing tip which remains enclosed within the primordial mass, the developing sporotheca is raised off of the surface. After the stalk reaches its maximum height, the columella and all or much of the capillitium are produced by continued deposition of fibers from the stalk. In some cases, the capillitium is also formed by secretions starting from the peridium and growing towards the columella. The sporotheca peridium, which is often thin and fragile, is derived from the protoplasmic membrane and secreted materials. Finally the spores are cleaved out from the remaining protoplasm into uninucleate units with the secretion of wall materials around them.

A third type of sporocarp development appears to occur in Echinostelium minutum where the sporocarp is formed from a protoplasmodium as follows: a hemispherical mound occurs in the center of the stationary protoplasmodium (resembles a fried egg) which becomes the spherical initial that progressively elevates itself atop the tapering fibrillar stipe tube which contains debris and other materials in the lower regions, this occurs by the apparent secretions of the stalk material from the basal region of the sporocarp initial, with the columella and capillitia secreted as continuations of the stipe (Haskins 1971, Haskins \& Kerr 1978). Barbeyella is a genus of some interest since it is dark-spored and has been reported as having an epihypothallic type development (Schnittler at al. 2000) like the Stemonitales (where it was once placed), but has lately been placed in the Echinosteliales on the basis of its protoplasmodium, general morphology and DNA studies (Fiore-Donno et al. 2012). Echinostelium minutum also shows some epihypothallic characteristics in that the sporothecal mass is raised up on an elongating stalk, however, the stalk is not enclosed in cytoplasmic material as it is progressive extended in length (Haskins 1971, Haskins \& Kerr 1978). Thus the Echinosteliales, which are considered to a sister group (Fiore-Donno et al. 2008, 2009, 
2012) to the dark-spored clade (Stemonitales and Physarales), appear to contain elements of both developmental types (Haskins 1971, Haskins \& Kerr 1978,). If this is so, and the Echinosteliales display traits ancestral to the other groups, then a hypothesis concerning the relationships of the developmental types can be constructed. In an ancestral organism with a minute sporocarp a stalk consisting of a moderately thin outer layer (composed of slime and condensed cytoplasmic materials) with fibers secreted just under it, would produce an extending stalk with the cytoplasmic mass on its apex. In the development of a larger sporangium with a thin weak outer membranous layer, the stipe could be produced by the deposition of extending fibers (with the outer layer nonexistent or lost) with the sporogenous mass above and draped over the stalk. While in the development of a larger sporangium with a thick outer layer, the deposition of extending fibers inside a wide column would produce a stalk with the cytoplasmic mass inside and on top, with the final stalk produced by the migration of the protoplasm to the top and a longitudinal pleating of the stalk as it dries. In the Echinosteliales and Stemonitales types, the columella and part of the capillitia would also be formed as a continuation of the stalk, while in the Physarales type, the columella would result from the expansion of the stalk fibers and the laying down of basal peridiallike materials over the stalk tip. The capillitia in the Physarales type of development originate from the peridium and grow to the columella (Weldon 1955), as do the capillitia which form the capillitial surface net in Stemonitales (Ross 1973). Thus the epihypothallic and subhypothallic developmental types are connected and probably derived from an ancestral Echinosteliales system, which represent a third developmental type. Apparently the diverse developmental systems of the myxomycete sporocarps are all modifications of two related processes: the general deposition of fibers to form a surface and the point deposit of fibers to form elongating structures. While this hypothesis would require some selected developmental studies (especially in Clastoderma, Barbeyella and Echinostelium arboreum) to validate it, it does have the current virtue of providing an explanation for the apparently diverse developmental processes found in the myxomycetes, that seemed to run counter to DNA phylogeny (Fiore-Donno et al. 2008). The developmental differences between Stemonitales (epihypothallic) and Physarales (subhypothallic), which appeared to be major, can now be seen as a more or less continuous system connecting the Echinosteliales, Stemonitales and Physarales orders in a manner similar to that detected by DNA phylogeny. A similar situation may occur in the light/bright-spored clade (Liceales, Trichiales), where the small sporangia of the Cribrariaceae may display a Echinostelium like development (Lado et al. 1999, Garcia Sastre et al. 2005), while the Trichiales have a subhypothallic system (Mims \& Rogers 1975). Time-lapse sequences of Didymium (subhypothallic), Stemonitis (epihypothallic) and Echinostelium (the possible third type of development) have been produced and published (Haskins and Kerr 1976).

\section{Stipes}

Stipes are apparently ancestral traits in the myxomycetes since they occur in the earlier branching genera (Echinostelium, Cribraria) as determined by DNA phylogeny (Fiore-Donno et al. 2005, 2012, 2013); where they would be especially useful in spore dispersal in these minute sporocarps. The stipe in the Echinosteliales is a smooth hollow tube stuffed with granular debris in the lower region, and it is composed of fibrillar elements, that start in the small hypothallic region and extend into the sporotheca as a generally solid columella (Haskins 1971). Semimorula liquescens, which was recently assigned to this group by DNA studies (Fiore-Donno et al. 2009), is the only non-stipitate species in the order.

In the Liceales, the three families apparently vary considerable in terms of the presence and morphology of the stalk. Liceaceae generally have small sessile sporangia with occasional constricted bases or distinct stipes (Wrigley de Basanta \& Lado 2005). Since most species in this group seem to be associated with the bark of living trees, the need for a stalk to reach turbulent air has been achieved and this has apparently allowed for the general loss of the stalk. The stipe, when present, appears to be continuous with the peridium and contains amorphous materials, and thus may have a developmental system similar to that found in the Trichiales. The only genus in the 
Tubiferaceae that has a stipe is Tubifera, and in these species the stipe is united into small groups or pseudoaethalial clusters. These stalks are also continuous with the peridium and may also be similar to the Trichiales. All species of Cribrariaceae are stipitate, although Lindbladia tubulina is generally a sessile aethalium with occasional vestigial stipes. The Cribraria species, on the other hand, have distinct stipes, although some specimens may appear sessile. The stipe which has a small hypothallus and generally lacks a columella, is usually slender, dark, somewhat furrowed and continuous with the peridium and its surface net. Limited evidence (Lado et al. 1999, Garcia Sastre et al. 2005) indicates that stipe development in this family, which may represent an ancestral state in the light-spored clade (Fiore-Donno et al. 2005), may be similar to that found in the Echinosteliales.

When present, the stipe, in the Trichiales, never has a columella and the stalk tube often widens out into a cup-shaped peridial calyculus. This order apparently has a general subhypothallic developmental system with a continuum of the outer stalk wall with the peridium and a inner core filled with amorphous materials (Mims \& Rogers 1975). Since there is little variation in the stipes of Trichiales, except for its presence, length and the formation of a calyculus, it has not played a major role in the taxonomy of this group. However, the presence of spore like bodies in the stalk may be a useful character since Trichia decipiens which has been grouped with several Hemitrichia species by DNA (Fiore-Donno et al. 2013) analysis, also shares this trait.

The Stemonitales, which are characterized by their epihypothallic stipe development, all have rather similar stipes; a dark hollow or solid tube with a hypothallus and a columella consisting of extensions of the stalk fibers. However, stipe structure has been fairly recently used (Ing \& Nannenga-Bremekamp 1966, Nannenga-Bremekamp 1967, Nannenga-Bremekamp et al. 1984) in a major taxonomic rearrangement of this order: genera having hollow stipes: Stemonitis (having a surface capillitial net), Stemonaria (lacking a surface net), Symphytocarpus (short stiped pseudoaethalial with no net), and Macbrideola (scanty capillitia not forming a net); genera having solid stipes: Comatricha (stalk tube of interwoven fibers, capillitium may form a partial net), Paradiacheopsis (stalk tube of interwoven fibers, capillitia dichotomously branching only), Stemonitopsis (stalk tube of interwoven fibers only at the base), Collaria (stalk tube fibers not interwoven, peridial collar on stalk), and Lamproderma (stalk tube fibers not interwoven, peridium persistent); genera having lime on the stipe: Diachea; and the remaining genera having very short or no stipes: Elaeomyxa (wax on sporocarp) Colloderma (slime on the sporocarp), Brefeldia (aethalium or pseudoaethalium, capillitial with chambered vesicles) Amaurochaeta (aethalium or pseudo-aethalium, capillitium without chambered vesicles), Diachaeopsis (persistent peridium, no columella) and Paradiachea (persistent peridium, columella present). The stalk in Enerthenema, a genus with capillitium arising only from an apical cup, was not discussed. While some of these stalk characteristics are supported by DNA phylogeny (Fiore-Donno et al. 2009) others have not yet been addressed or they are contradicted. The division of the genera into hollow and solid stalked groups is highly supported by these studies (a possible family level character); however, the absence of a stalk is not supported as a genus level character. The stipe-less genera Diachaeopsis, Colloderma and Elaeomyxa apparently do not form coherent groups and are usually dispersed within the Lamproderma clade. Collaria, defined by its stalk collar, as represented by Collaria (Lamproderma) arcyrionema is also found within the Lamproderma clade.

The species in the order Physarales have a typical subhypothallic developmental stipe (Guttes \& Rusch 1961), and the stipe is not generally used as higher level taxonomic character other than its presence or absence. However, there appears to be useful stalk variations that can be used at the species level. Matsumoto (1999) has shown, in Didymium, that such stipe characteristics as fiber tube shape (heavily pleated or not), fiber tube thickness (thick to absent); core size and materials (present, absent, lime present or absent); and exterior lime (present or absent), can be used to help define and group the species. However, the use of these variations as taxonomic characters; requires knowledge of the structure's development and the range of the variations found within the taxon, since not all variations are taxonomically valid. For example, the columella in many species is not so much an intrusion into the sporothecal space, but a folding back 
of the sporotheca around the stalk tip to form a umbilicus which may remain open or become closed with the stalk; this can produce a compound columella consisting of the stalk tip and the peridial wall that encloses it (Welden 1955). The appearance of this columella can vary greatly due to slight differences in development, and thus care must be used when using this character; for example, the generally accepted species Didymium bahiense, mainly separated from Didymium iridis on the basis of columella shape, may belong to the same reproductive group as a $D$. iridis (Clark \& Mires 1999).

\section{Capillitia}

The capillitium is generally a network structure which supports the spores in the mature sporocarp, and is apparently involved in spore dispersal. However, a capillitium is not present in all species, and when present it can be reduce and rudimentary. All species in the order Echinosteliales have minute sporocarps, which can have an open capillitial net, a few branched meshes, or completely lack any evidence of capillitia. When present, the capillitia appear to be smooth, hollow threads originating from (and probably part of) the columella.

The order Liceales, which is probably a somewhat artificial group, lacks true capillitia by definition (Martin \& Alexopoulos 1969), but pseudocapitillia are generally present in the Tubiferaceae, and a capillitial-like surface network derived from the peridium, is always found in the Cribrariaceae; while the Liceaceae generally has very small sporangia which completely lack any capillitia-like elements, except for wart-like processes or tubular outgrowths from the peridium found in some species (Kowalski 1967, Keller \& Brooks 1971). Alexopoulos (1976) and Eliasson (1977) have suggested that several Licea spp. may represent reduced or basal Perichaena which lack capillitia; however, DNA studies (Fiore-Donno et al. 2013) indicate that Licea variabilis may actually be a reduced Dianemataceae species. Little information is available concerning the development of these capillitial-like elements in the Liceales; most likely because they are seldom or never grown in culture where extensive studies could be undertaken. Pseudocapillitia may consist of long branched strands that resemble capillitia, or thin perforated membranes scattered within the aethalium. When capillitial-like structures are present, as in Lycogala, they are generally more irregular in size and shape than true capillitia. And in Dictydiaethalium, which is intermediate between an aethalium and a pseudo-aethalium in form, the pseudocapillitia has been considered to be derived from the corner remnants of the sporangial walls where they were pressed together; however, these structures may be actual capillitia since recent DNA studies (Fiore-Donno et al. 2013) indicate that this genus is related to Dianemataceae in the Trichiales. While the surface net of the Cribrariaceae are apparently derived from the peridium, it is also possible that they may represent the evolutionary remnants of a reduced capillitial system.

As far as it is known, the capillitium of the Trichiales, is formed by the secretion of materials into a vacuolar system (Mims \& Rogers 1975) which forms an often abundant and ornamented system. Apparently the polymerization of the capillitial fibers release water into the lumen which is released at the tip of the fibers, which then shrink to show the spiral banding (McHugh et al. 2000). The order is divided into two families on the basis of capillitial characteristics: Dianemataceae with solid threads which are generally smooth and never united into a complex network and Trichiaceae with tubular threads which are generally highly ornamented and often united into a net. This separation has become more difficult to maintain since the demonstration of a continuous series from solid to hollow within the two families (Kowalski 1967, Ellis et al. 1973, Keller at al. 1973). However, if Listerella and Minakatella are removed the remaining two genera, Dianema and Calomyxa, may warrant the retention of Dianemataceae, since they have solid or filled capillitia at least partially attached to both the peridium and sporothecal base, similar membranous two-layered peridia and pallid to yellowish-colored spores (Eliasson 1977). Listerella, a rare and little known genus, consisting of a single species, with scanty, flexuous capillitial threads and a protoplasmodium, is essentially a Liceales with a capillitium; thus Kowalski (1976) suggested that it should be included in Liceaceae. And Minakatella, also with a single species, has tubular capillitia and it has been suggested (Keller at al. 1973) that it should also 
be transferred to the Trichiaceae. On the other hand, Prototrichia, which is generally placed in the Trichiaceae, since it has a somewhat open capillitium lumen, apparently belongs in the Dianemataceae since general morphology and DNA studies (Fiore-Donno et al. 2013) seem to place it there. Thus Dianemataceae, which seems to be intermediate between Liceales and the rest of the Trichiales, would consist of Dianema, Calomyxa, Prototrichia, Dictydiaethalium, and possibly some Licea species. The capillitium in the Trichiaceae appears to be especially active in spore dispersal, since it is often expansive (producing a larger open spore mass) or hygroscopic (loosens the spore mass), thus producing a structure that helps maximize spore dissemination.

These prominent structures are quite varied; some bearing spiral bands which may also have ornamental spines, united into a network (Hemitrichia) or existing as separate filamentous elaters (Trichia); some lack the spiral bands, but may be ornamented with spines, cogs or rings and united into a network (Arcyria) or consisting of simple or branched threads (Perichaena). While, capillitia play an important role in the taxonomy of this order, and seem to produce natural groups, some species have capillitial characters which grade into species in other genera (Martin \& Alexopoulos 1969, Eliasson 1977); and DNA studies (Fiore-Donno et al. 2013) indicate that while Perichaena, Hemitrichia, and Arcyria (including Arcyodes) are apparently distinct genera; Trichia species form a complex with Cornuvia, Oligonema and Metatrichia species, and Trichia decipiens is associated with the Hemitrichia.

It appears that the capillitia in the Stemonitales are produced by the intraprotoplasmic secretion of materials which are continuations from the columella or newly originating from the peridium (Ross 1973, Goodwin 1960). Haskins' (1974) film on the plasmodial stage of Stemonitis flavogenita contains a sequence that shows the sequential formation of a capillitial fragment and its subsequent attachment to the developing capillitium. The columella is composed of fibrillar strands that form a hollow or solid tube and the resulting capillitia consists of continuations of these fibers, and, in species that form a surface net, they connect to fibers laid down in the cytoplasm which presumably originate from the peridium. The capillitia in this order are, in general, rather similar, however, the presence or absence of a surface net and the place of origin of the capillitia on the columella, have been used as taxonomic characters (see information in stipe discussion). The presence of a surface net is generally correlated with a hollow stalk tube and thus has some validation as a generic character, however, the origination of the capillitia from the columella does not seem to be a good character at the genus level since several Enerthenema species (define by the apical capillitia origin) are close to a Comatricha clade by DNA phylogeny (Fiore-Donno et al. 2009),

Capillitia are generally present in the Physarales, although they may be nearly absent or rudimentary; and are formed by the secretion of materials into a network of vesicles (Guttes \& Rusch 1961). The major capillitial variations in this order are in branching (rudimentary, dichotomous, and netted) and the presence and absence of lime (none, nodules, tubes). The rudimentary and netted capillitia are usually associated with sessile sporocarps, and the dichotomously branching capillitia with stipitate sporangia; and therefore, do not seem to be valid characters for generic taxonomy (Matsumoto1999). In fact, there is considerable controversy concerning the separation of Didymium comatum (Nannenga-Bremekamp 1966) from Didymium difforme, on the basis of abundant netted versus dichotomous branching capillitia, since the two forms are found together in the same fruiting (Martin \& Alexopoulos 1969). On the other hand, while the presence or absence of lime on the capillitia, as a character separating the Physaraceae from the Didymiaceae, has been confirmed by DNA studies (Fiore-Donno et al. 2009, Nandipati et al. 2012), the separation of Badhamia from Physarum on the basis of lime tubes versus nodules has not been supported, as previously suspected by a number of taxonomists. Although the capillitia in this order have a fairly standard morphology, there are a few species which are rather unique; Didymium eremophilum, a small desert species completely lacks a capillitium (Blackwell \& Gilbertson 1980), and the capillitium in Didymium subreticulosporum is replacement by strands of crystalline lime (Mosquera et al. 2000). 


\section{Peridia}

The peridium is the outer covering of the sporotheca that is found in all endosporic species, although it may be very delicate and disintegrate at maturity, and in some species even the formation of a distinct peridium has been questioned (Macbride \& Martin 1934). It is a noncellular structure and consists of one or more layers of a fibrillar mucopolysaccharide matrix (Rhea 1966, McCormick et al. 1970, Simon \& Henney 1970, Cheung et al. 1974, Charvat et al. 1973, Raub \& Aldrich 1982) that may have embedded or encrusted lime deposits. This mucopolysaccharide material and lime appears to be mobilized to the surface by vacuoles and invaginations of the plasmalemma into the ectoplasm (Achenback et al.1979, Schokneckt \& Keller 1989). In Perichaena vermicularis, the mature peridium is produced by autolysis of the outer layer of cytoplasm and the laying down of fibrillar materials under a thin layer of slime sheath and excreted materials (Charvat et al. 1973). The inner peridial wall appears to have distinct morphological features in a number of species (Eliasson \& Sunhede 1980, Rammeloo 1974a); however, this is a rather amorphous character that requires extensive study to insure that an adequate knowledge of its variations has been determined. The number of layers in a peridium is another variable trait that can cause taxonomic problems. For example in most species of Perichaena the peridium splits into two layers, but in Perichaena vermicularis and Perichaena luteolum it remains a single layer. Gilbert (1995) transferred the latter species from Calonema since it was identical to Perichaena in all other aspects. Also, the lime, in the Physarales, often forms a distinct layer separate from the rest of the peridium, and can thus cause confusion as to the number of layers present.

The peridium, in species of Echinosteliales, is generally a delicate membrane that does not persist in the mature sporangium; however, in several species the peridium separates along preformed lines and may persist as irregular or platelet fragments attached to the capillitial tips: Barbyella minutissma (Schnittler et al. 2000), Clastoderma debaryanum (Frederick et al. 1986, Eliasson \& Keller 1996), and Echinostelium arboreum (Haskins \& McGuinness 1989). However, it has been suggested that these peridial platelets of Clastoderma and Barbyella are actually part of the capillitium (Frederick et al. 1986, Schnittler et al. 2000).

The three families in the Liceales show considerable variability in their peridial structures. The peridium in the Liceacae are usually tough and has a papery or leathery consistency, which may consist of two layers that range from thin to thick and sometimes have a gelatinous or slimy covering. At maturity the sporocarps release their spores by means of irregular or platelet fragmentation, circumscissle or slit dehiscence, or by means of opercula. The peridia in the genera of the Tubiferaceae are also varied: in Tubifera the peridium is usually a persistent membranous structure that dehisces by apical fragmentation, in Dictydiaethalium the pseudoaethalium has a cortex that is made up of the united membranous apical portions of the individual sporangia, in Lycogala the aethalium which develops from papillae which partition the cortical material which then splits to form the air filled pseudocapillitia (McHugh \& Reid 2008), this cortex can varies from a thick and firm leathery structure to a delicate membrane, and the species are usually identified by the presence and morphology of the surface warts on the cortex, which releases spores from an apical dehiscence region; in Reticularia the cortex varies from a tough persistent firm structure with irregular dehiscence to a thin and evanescent membrane. In all of the species in the family Cribrariaceae the peridium is a delicate evanescent membrane with a network of persistent capillitial-like ribs which bear minute calcium containing dictydine granules, although the peridium in Lindbladia may be persistent.

The peridia in the Trichiales, which may consist of several layers, varies from a thin translucent membrane to a tough cartilaginous structure, that can be smooth, patterned or covered with granules. Spore release is often by irregular dehiscence, but a number of genera or species have fairly distinct patterns: operculate (Metatrichia vesparia), fugacious above with a persistent peridial calyculus (Arcyria, Arcyodes, and Trichia decipiens), irregular apical dehiscence (Trichia), and circumscissle (Perichaena depressa). 
The genera in the Stemonitales are divided into three groups by a basic peridial character: those with thin membranous peridia that are fugacious at maturity (Brefeldia, Amaurochaete, Symphytocarpus, Stemonitis, Comatricha, Enerthenema), those with thin membranous peridia that retain a collar or attached fragments at maturity (Macbrideola, Paradiacheopis, Meriderma), and those with a thin shining persistent peridia at maturity (Diachea, Diachaeopsis, Paradiachea, Elaeomyxa, Colloderma, Lamproderma). However, recent DNA phylogeny studies (Fiore-Donno et al. 2012) have shown that the sessile genera Diachaeopsis, Elaeomyxa (also have waxy peridial deposits), and Colloderma (also have slimy peridial deposits) are interspersed within the Lamproderma clade and therefore are probably not valid taxa. Also Meriderma, a genus recently segregated from Lamproderma, on the basic of a evanescent peridium that stays attached to the ends of the capillitial tips (Poulain et al. 2011), is supported by these DNA studies; but Collaria, based on a persistent peridial collar, is found within the Lamproderma clade.

The peridia of the Physarales generally consist of one or more membranous to cartilaginous layers with associated lime deposits. However, the cortex of the Fuligo species consists of a mix of peridial material and the empty crushed outer sporangial cells of the aethalium (Martin \& Alexopoulos 1969). Spore dispersal, in the Physarales, is effected by means of breakage of the peridium into small fragments along preformed lines with the fragments often remaining attached to the capillitia ends, by irregular or circumscissle dehiscence of large peridial fragments, or by means of a preformed operculum. The lime deposits have been used as taxonomic characters at both the species and higher levels (also see lime under general characteristics). The separation of the order into the families Physaraceae (amorphous lime) and Didymiaceae (crystalline lime) on the basic of lime types has been supported by DNA phylogeny (Fiore-Donno et al. 2009). The genus Diderma is characterized by lime enmeshed within the cartilaginous peridium, and the genus Lepidoderma is characterized by its relatively large flat scale-like particles on the peridial surface. Species level lime deposit variations are: loose powders, flakes, crusts, or smooth egg-shell like coverings.

\section{Spores}

Spores are cleaved out of the sporothecal protoplasm by means of vesicle fusion which produces uninucleate segments of protoplasm around which spore wall materials are deposited (Mims 1972). These spore walls generally have a variety of ornamentations which are often used as taxonomic character at the species level, although they are often at the limit of light microscopic resolution in many species. This difficulty has been overcome by the use of the electron microscope to elucidate details of spore ornamentation (Scheetz \& Alexopoulos 1971, 1976, Rammeloo 1974b, 1975, Demaree \& Kowalski 1975, Haskins \& McGuinness 1986, Neubert \& Baumann 1987, Neubert et al. 1989, 1992, Lizárraga et al. 1999), and new terminology has been proposed (Rammeloo 1974a). The ornamentations are classified as pila (swollen heads on a cylindrical base), bacula (cylindrical processes without a head), verrucae (irregular short processes), spines (long pointed processes), coni (short blunt pointed processes), muri (ridges having smooth surfaces), and cristae (ridges consisting of jointed pili, bacula or other processes), with individual spores having one or more types of processes. With the light microscope these ornamentations are usually classified as spines (spines and some coni), warts (pili, bacula and some coni) and ridges (muri, cristae). While spore ornamentation, shape, size and clustering are considered to be critical taxonomic character at the species level, spore characteristics have a limited utility at higher levels, except for spore color which generally divides the myxomycetes into the dark (Physarales and Stemonitales) and light/bright (Liceales and Trichiales) spored clades (Fiore-Donno et al. 2009, 2013). The spores of most species are in the range of 7 to 12 microns in diameter, but may be as small as 4 and as large as 20 microns (Gray \& Alexopoulos 1968). The majority are spherical in shape although a few are ovate or angular. A few species have clustered spores; however, they are generally rare and usually have a non-clustered spore counterpart that is identical or very similar to them (Schnittler \& Mitchell 2000). These spore characteristics are considered to be quite constant, especially at the species level, however, they can and do vary in 
different isolates of the same species (Martin \& Alexopoulos 1969, Gaither \& Collins 1984, ElHage et al. 2000, Fiore-Donno et al. 2011). In fact, as in the case for most characteristics, spore ornamentation, size and color may be all alike or vary in one collection to another of the same species. Therefore, a number of isolates must be studies to determine the morphological range of spore characteristics for a particular species, which in certain cases may be quite wide.

\section{General Characteristics}

\section{Lime}

The mature sporophores of many myxomycete species have various deposits of calcareous materials which are often distinct and have been found to provide useful taxonomic characteristics. This material has traditionally been designated as lime (calcium carbonate), however, X-ray diffraction studies (Schokneckt \& Keller 1989) have shown that a number of different calcium compounds may be present in the different calcareous and non-calcareous species. A major distinguishing characteristic of the order Physarales is the presence of lime on the mature sporocarps, and its two families, Physaraceae and Didymiaceae, are separated on the basis of lime deposits. All Didymiaceae species studied, to date, have stellate crystalline or spheroid cryptocrystalline calcium carbonate (Schokneckt 1975) and the lime seldom occurs on the capillitium, while in the Physaraceae the amorphous lime, which almost always occurs on the capillitium, contains phosphorous as well as calcium (Schokneckt 1975). This lime, in Physarella oblonga, is first secreted into small spheres before being transferred to the surfaces (Bechtel \& Horner 1975); while, in Didymium squamulosum, it is deposited directly upon the surfaces (Gustafson \& Thurston 1974). If this difference is found to hold for other species it would be an additional trait separating the two families. Therefore, it seems that these two types of lime deposits are useful markers, which are also supported by DNA studies (Fiore-Donno et al. 2009, Nandipati et al. 2012), for Physaraceae and Didymiaceae. However, considerable care may be required in their use regarding some species and specimens; since, lime deposits are sensitive to variable environmental conditions during formation and the typical appearance of the deposits may be altered or much reduced. This variability is especially evident in cultured material. For example, many isolates of Didymium squamulosum lack obvious stipe lime when cultured on agar and appear to be very similar, if not identical, to collections from nature that were identified as Didymium marineri (ElHaga et al. 2000); and Squamuloderma (Didymium nullifilum, which was based on a single cultured isolate (Kowalski 1972), with only minimal lime deposits, is in all probability inadequate material for a species description. Aldrich (1982) has also shown that lime color, in the Physarales, may be subject to the uptake and accumulation of various inorganic ions from the environment; a conclusion supported by the finding of typical white limed Physarum globuliferum sporangia when a blue limed Physarum bilgrami specimen was grown in culture (Henney 1968). Also, some species that otherwise appear to be valid members of the Physarales, such as the minute Protophysarum phloiogenum and Didymium eremophilum have apparently lost or greatly reduced their obvious lime deposits. The genus Diachea, normally assigned (Martin \& Alexopoulos 1969) to the generally lime less Stemonitales, poses an especially difficult problem, in regards to lime, since it has abundant deposits of lime, containing calcium and phosphate (Schokneckt 1975), on it stipe, and in Diachea bulbillosa this lime is crystalline in collections from the tropics and granular on collections from temperate regions (Farr 1974). While only a few species or genera in other orders have obvious lime deposits on their sporocarps, calcium compounds (such as calcium oxalate) appear to be common in various species in Cribrariaceae (Schokneckt 1975), Dianemataceae (Schokneckt \& Keller 1978) and Trichiaceae (Nelson et al. 1977, Schokneckt \& Keller 1978).

\section{Color}

While the color of the sporophore of most myxomycete species is a rather drab white or brown, a wide variety of colors, which have been found useful as taxonomic characters, occurs in 
other species. However, these colors appear to be rather variable within a species, and their underlying basis is poorly understood. A complex variety of organic chemicals, besides the inorganic ion colorations found in the lime (Aldrich 1982), have been reported in sporophores and plasmodia; these include indoles (Stelich et al. 1980), tetrameric acid derivatives (Casser et al. 1987), carotenoids (Czeczuga 1980), pteridines (Blackwell \& Busard 1978), melanins (Loganathan et al. 1989) and naphthoquinones (Iwata et al. 2003), Thus, simple color may be misleading, since two yellow pigments may be due to chemically different compounds, while a red and a yellow pigment could be closely related chemically. However, an understanding of the chemical nature of the pigments can be of considerable value. For example, the melanin in the taxonomically difficult genus Diachea, is more similar to that found in the Stemonitales than that found in the Physarales (Loganathan et al. 1989, Kalyanasundaram \& Ali 1989). Also pigment variations, detected by chromatography, have been found useful to distinguish between several similar yellow species of Hemitrichia (Blackwell \& Busard 1978) and also between red species of Arcyria (Rebhahn et al. 1999). However, inherited color variants can also occur within a species. In Didymium iridis, the taxonomically important stipe color has been shown to vary directly (Clark \& Mires 1999) with the color of the plasmodium, which can vary from brown or cream colored on the basis of two genes (Collins \& Clark 1966, Collins \& Erlenbacher 1969). Outside of the effect of colored pigments many myxomycetes also display structural color in the form of iridescence, which has recently been shown, in Diachea leucopodia, to be produced by light interference due to the corrugated transparent peridial material with inhomogenities and its curvation (Inchaissandague et al. 2010, Dolinko et al. 2012).

\section{Size}

The sporophores of the myxomycetes range in size from the minute sporangium of Echinostelium bisporum to the large aethalium of Fuligo septica, however, within a species the sporophore seldom exceeds a twofold range. On the other hand, occasional collections are found that conform to a species description in general except for size. These collections are usually a miniature form of a widespread species and have been considered to be biotypes evolved for special habitats (Clark et al. 2001). These collections are usually found in ephemeral habitats where rapid growth and sporulation is necessary if the life cycle is to be completed. A number of collections have been grown in culture and they retain their miniature sporocarp form: a Didymium iridis isolate from an inflorescence (Clark et al. 2001), several Arcyria cinerea isolates from aerial litter (Clark et al. 2002), and five Physarum pusillum isolates from aerial litter and inflorescences (Clark et al. 2004). While it might be possible to assign these collections to new species, they appear to be specialized asexual (non-heterothallic) clonal populations derived from widespread species.

\section{Discussion}

Our understanding of myxomycete sporophore morphology has been greatly enhanced by the application of developmental and electron microscopical studies to this area. Interestingly, sporocarp development is apparently not just a simple dichotomy of epihypothallic and the subhyphothallic types. Not only is there is a third Echinostelium developmental type which is probably ancestral to the other types, but the subhypothalic type in the Physarales and Trichiales must have separate origins if the current DNA phylogeny (the Physarales clade branching from the Stemonitales clade) is correct. While continued studies in these methods are needed, especially in some of the lesser known groups, a major challenge, of the present day, will be to determine the systematic validity of these morphological structures and their variations. Fortunately, we now have a growing number of genetic reproductive studies (see Clark \& Haskins 2010), DNA phylogeny studies (Fiore-Donno et al. 2005, 2008, 2009, 2010, 2012, Nadipati et al. 2012, 2013), and isozyme and DNA populations studies (ElHage et al. 2000, Irawan et al. 2000, Winsett \& Stephenson 2008, 2012, Fiore-Donno et al. 2011), against which morphological hypothesis can be tested. We now have good reason to believe that the majority of the widespread morphospecies in 
the myxomycetes have a complex population structure; consisting of a mix of a number of genetically separated sexual biological species and multiple clonal apogamic lines, which are also capable of long distance dispersal. This suggests that the myxomycete morphospecies, in general, are divided into many small genetically isolated dispersed population units in which minor morphological variations could and almost certainly do accumulate. Thus, the validity of many minor morphological variations as species determinants; must be considered as doubtful until they have been examined in a number of sporophores from within and between different collections with due regard to the developmental plasticity exhibited by the myxomycetes. This problem is illustrated by Schnittler and Mitchell's (2000) examination of the accelerating description of new species of myxomycetes; where they found that an increasing number of the new species appeared to be very rare and were often known from only a single type locality. They also provided a list, which we fully endorse, of criteria that should be used to evaluate candidates for new taxa. In terms of higher level morphological taxonomic characteristics, we agree with Schnittler \& Spiegel (2012) that more research is needed on characteristics that would help determine the relationships within and between the genera and families of Liceales, that could stabilize the genera determinations in the Stemonitaceae, and that would find reliable and valid characters that would provide genera separation in the Physaraceae. While myxomycete sporophore morphology and development are useful taxonomic characters, and are interesting in them self, one should never forget that the function of the sporophore is the production and dispersal of the spores which are necessary for the survival of the species.

\section{Acknowledgements}

This review is an attempt to distill the work and ideals of a great many researchers. However, such an attempt can never do justice to everyone's contribution, and we can only say that we tried to do our best, and hope that we have not committed too many major omissions.

A special acknowledgement is extended to the Biodiversity Heritage Library which provided electronic versions of the following rare publications: The Myxomycetes of Great Britain by MC. Cooke (1877) and A Monograph of the Myxogastres by G. Massee (1892).

\section{References}

Achenbach F, Naib-Majani W, Wohlfarth-Botterman KE. 1979 - Plasmalemma invaginations of Physarum dependent on thenutritional content of the plasmodial environment. European Journal of Cell Biology 36, 355-359.

Aldrich HC. 1983 - Influence of inorganic ions on color of lime in the myxomycetes. Mycologia 74, 404-411.

Alexopoulos CJ. 1973 - The Myxomycetes. In (Eds Ainsworth GC, Sparrow FK, Sussman AS) The Fungi. Vol. IVB.

Alexopoulos CJ. 1976-Absence of capillitium as a taxonomic character in the Myxomycetes. Transactions of the British Mycological Society 66, 329.

Baker GE. 1933 - A comparative morphological study of the myxomycete fructification. University Iowa State Natural History 14, 1-35.

Bechtel DR, Horner HT. 1975 - Calcium excretion and deposition during sporogenesis in Physarella oblonga calcification. Calcareous Tissue Research 18, 195-213.

deBary A. 1886 - Morphologie und Physiologie der Pilze, Flechten, und Myxomyceten. In Hofmeister's Handbuch der Botanik 2. Abt. 1. Engelmann, Leipzig.

Blackwell M, Busard A. 1978 - The use of pigments as a taxonomic character to distinguish species in the Trichiaceae (Myxomycetes). Mycotaxon 7, 61-67.

Blackwell M, Gilbertson RL. 1980 - Didymium eremophilum: a new myxomycete from the Sonoran desert. Mycologia 72, 791-798.

Casser I, Steglich W. 1987 - The chemistry of the plasmodial pigments of the slime mold Fuligo septica (Myxomycetes). Angewandte Chemie 28, 586-587. 
Charvat I, Ross IK, Cronshaw J. 1973 - Ultrastructural of the plasmodial slime mold Perichaena vermicularis II. Formation of the peridium. Protoplasma 78, 1-19.

Cheung L, Henney HR, Clark WH. 1974 - Ultrastructure of the plasmodial slime mold Physarum flavicomum 1. Conversion of a plasmodium to microplasmodia and microsclerotia and the process of slime secretion. Cytobios 9, 193-205.

Clark J. 2000 - The species problem in the myxomycetes. Stapfia 73, 39-53.

Clark J, Haskins EF, Stephenson SL. 2004 - Culture and reproductive systems of 11 species of Mycetozoans. Mycologia 96, 36-40.

Clark J, Mires A. 1999 - Biosystematics of Didymium: the non-calcareous long-stalked species. Mycotaxon 71, 369-382

Clark J, Schnittler M, Stephenson SL. 2002 - Biosystematics of the myxomycete Arcyria cinerea. Myotaxon 82, 343-346.

Clark J, Stephenson SL, Landolt JC. 2001 - Biosystematics of the Didymium iridis super species complex: additional isolates. Mycotaxon 70, 447-454.

Collins OR. 1979 - Myxomycete biosystematics: some recent developments and future research opportunities. Botanical Review 45, 145-201.

Collins OR, Clark J. 1966 - Inheritance of the brown plasmodial pigment in Didymium iridis. Mycologia 58, 743-751.

Collins OR, Erlebacher B. 1969 - Effects of two mutations of a red plasmodial pigment in the myxomycete Didymium iridis. Canadian Journal of Botany 15, 1245-1247.

Cooke MC. 1877 - The Myxomycetes of Great Britain. William and Norgate, London.

Czeczuga B. 1980 - Investigations on carotenoids in fungi VII. Representatives of the myxomycetes genus. Nova Hedwigia 32, 347-354.

Demaree R, Kowalski D. 1975 - Fine structure of myxomycetes with clustered spores. Journal of Protozoology 22, 85-88.

Dolinko A, Skigin D, Inchaussandague M, Carmanran C. 2012 - Photonic simulation method applied to the study of structural color in Myxomycetes. Optics Express 20, 15139-15148.

ElHaga N, Little C, Clark C, Stephenson SL. 2000 - Biosystematics of the Didymium squamulosum complex. Mycologia 92, 54-64.

Eliasson U. 1977 - Recent advances in the taxonomy of Myxomycetes. Botaniska Notiser 130, 483-492.

Eliasson U, Keller HW. 1996 - The genus Clastoderma: taxonomic evaluation and infraspecific variation of $C$. debaryanum. Mycological Research 100, 601-609.

Eliasson U, Sunhede S. 1980 - External structure of peridium, pseudocapillitium and spores in the myxomycete genus Lycogala Adams. Botaniska Notiser 130, 483-492.

Ellis TT, Scheetz RW, Alexopoulos CJ. 1973 - Ultrastructural observations on capillitial types in the Trichiales (Myxomycetes). Transactions of the American Microscopical Society 93, 6579.

Farr ML. 1974 - Some new myxomycete records for the neotropics and some taxonomic problems in the myxomycetes. Proceedings of the Iowa Academy of Science 81, 37-40.

Fiore-Donno AM, Berney C, Pawlowski J, Baldauf SL. 2005 - High-order phylogeny of plasmodial slime molds (Myxogastria), based on elongation factor 1-A and small subunit rRNA gene sequences. Journal of Eukaryotic Microbiology 52, 201-210.

Fiore-Donno AM, Clissmann F, Meyer M, Schnittler M, Cavalier-Smith T. 2013 - Two-gene phylogeny of bright spored myxomycetes (Slime moulds, Superorder Lucisporidia). PLos ONE 8(5), e62586.

Fiore-Donno AM, Haskins EF, Pawlowski J, Cavalier-Smith T. 2009. Semimorula liquescens is a modified echinsteloid myxomycete (Mycetozoa). Mycologia 101, 773-776.

Fiore-Donno AM, Kamono A, Meyer M, Schnittler M, Fuku M, Cavalier- Smith T. 2012 - 18s rRNA phylogenics of Lamproderma and allied genera (Stemonitales, Myxomycetes, Amoebozoa). PLos ONE 7(4): e35359. 
Fiore-Donno AM, Meyer M, Baldauf SL, Pawlowski J. 2008 - Evolution of dark-spored Myxomycetes (Slime-molds): molecular versus morphology. Molecular Phylogentics and Evolution 46, 878-889.

Fiore-Donno AM, Nickolaev SL, Nelson M, Pawlowski J, Cavalier-Smith T, Baudauf SL. 2009 Deep phylogeny and evolution of slime moulds (Myxomycetes). Protist 161, 55-70.

Fiore-Donno AM, Novozhilov YK, Meyer M, Schittler M. 2011 - Genetic structure of two Protist species (Myxogastria, Amoebazoa) suggest asexual reproduction in sexual amoebae. PLos ONE 6, e22872.

Frederick L, Roth IL, Pendergrass L. 1986 - Observations of the "peridial platelets" of Clastoderma debaryanum. Mycologia 78, 263-268.

Gaither T, Collins OR. 1984 - Comparative SEM observations of sporophore characteristics of three species of Didymium (Myxomycetes, Physarales). Mycologia 76, 650-664.

Garcia Sastre M, Estrada-Torres A. 2005 - Observations on the moist chamber culture of some Cribraria species. In Fifth International Congress of Systematic and Ecology of Myxomycetes, p35. Univeridad Automoma de Tlaxcala, Tlaxacala, Mexico.

Gilbert E. 1995 - Taxonomic evaluation of the myxomycete Calonema luteolum Mycological Research 99, 311-316.

Goodwin DC. 1961 - Morphogenesis of the sporangium of Comatricha. American Journal of Botany 48, 148-154.

Gray WD. 1937 - Observations on the method of stipe formation in Stemonitis and Comatricha. Proceedings of the Indiana Academy of Science 46, 81-85.

Gray WD. 1949 - The laboratory cultivation and development of the myxomycetes Physarella oblonga and Physarum didermoides. Ohio Journal of Science 49, 105-108.

Gray WD, Alexopoulos CJ. 1968 - Biology of the Myxomycetes. The Ronald Press, New York.

Gustafson RA, Thurston EL. 1974 - Calcium deposition in the myxomycete Didymium squamulosum. Mycologia 66, 397-412.

Guttes E, Rusch HP. 1961 - Morphological observations on growth and differentiation of Physarum polycephalum grown in pure culture. Developmental Biology 3, 588-614.

Haskins EF. 1971 - Sporophore formation in the myxomycete Echinostelium minutum de Bary. Archiv für Protistenkund 113, 123-130.

Haskins EF. 1974 - Stemonitis flavogenita (Myxomycetes) - Plasmodial phase (Aphanoplasmodium). Film E3000 des Institut für Wissenshaftlichen Film Gottingen. Publikationen zu Wissenshaftlichen Filmen Sektion. Biologie 8(1975), 1-14.

Haskins EF, McGuinness M. 1986 - Comparative ultrastructural observations of spore wall structure in six species of Echinostelium and three species of Eumycetozoa. Mycologia 78, 613-618.

Haskins EF, McGuinness M. 1989 - Sporophore ultrastructure of Echinostelium arboreum. Mycologia 81, 303-307.

Henney MR. 1968 - Mating type systems in the myxomycetes Physarum globuliferum and $P$. bilgramii. American Journal of Botany 55, 720.

Inchaussandague M, Skigin D, Carmaran C, Rosenfeldt S. $2010 \quad-\quad$ Structural color in Myxomycetes. Optics Express 18, 16055-16063.

Ing B, Nannenga-Bremekamp NE. 1966 - Notes on myxomycetes. XIII Symphtocarpus nov. gen. Stemonitacearum. Konienklijke Nederlandse Akademie van Weternschappen 70, 2172231.

Irawan B, Clark J, Stephenson SL. 2000 - Biosystematics of the Physarum compressum morphospecies. Mycologia 92, 884-893.

Iwata D, Ishibashi M, Yamamoto Y. 2003 - Cribrarione B, a new naphtha-quinone pigment from the myxomycete Cribraria cancellata. Journal of Natural Products 66, 1611-1612.

Jahn E. 1931 - Myxomycetenstudien. 13. Die Stielbildung bei den Sporangien der Gattung Comatricha. Berichte der Deutschen Botanischen Gesellschaft 49, 77-82. 
Kalyanasundaram I, Ali M. 1989 - Taxonomic note on the myxomycete genus Diachea. Mycological Research 93, 235-237.

Keller HW, Aldrich HC, Brooks TE. 1973 - Corticolous Myxomycetes II. Notes on Minakatella longifilia with ultrastructural evidence for its transfer to the Trichiaceae. Mycologia 65, 768-778.

Haskins EF, Kerr NS. 1976 - Vergleich der Plasmodien-Typen und der Sporulation bei Myxomyceten. Film C1220 des Institut für Wissenshaftlichen Film Gottingen. Publikationen zu Wissenshaftlichen Filmen Sektion. Biologie 27(1978), 1-34.

Keller HW, Brooks TE. 1971 - A new species of Perichaena on decaying leaves. Mycologia 63, 657-663.

Kowalski DT. 1972 - Squamuloderma: a new genus of myxomycetes. Mycologia 64, 1282-1289.

Kowalski DT. 1967 - Observations on the Dianemaceae. Mycologia 59, 1075-1084.

Lado C, Mosquera J, Beltrain-Tejera E. 1999 - Cribraria zonatispora, development of a new myxomycete with unique spores. Mycologia 91, 157-165.

Lado C, Pando F. 1997 - Flora Mycologia Iberica Vol 2. Myxomycetes I. Ceratiomyxales, Echinosteliales, Liceales, Trichiales. Cramer Verlag.

Lister A, Lister G. 1925 - A Monograph of the Mycetozoa. 3rd edition. British Museum London.

Lizárraga M, Illana C, Moreno G. 1999 - SEM studies of the Myxomycetes from the peninsula of Baja California (Mexico), II. Hemitrichia to Trichia. Annales Botanica Fennici 36, 187210.

Loganathan P, Paramasivan P, Kalyanasundarum I. 1989 - Melanin as the spore wall pigment of some myxomycetes. Mycological Research 92, 286-292.

Lucus S, Razin M, Kerr NS. 1968 - Observations on differentiation of plasmodia into fruiting bodies by the true slime mold, Didymium nigripes. Journal of General Microbiology 53, $17-21$.

Macbride TH, Martin GW. 1934 - The Myxomycetes. Macmillan Co. New York.

Martin GW, Alexopoulos CJ. 1969 - The Myxomycetes. University of Iowa Press, Iowa City.

Massee G. 1892. A Monograph of the Myxogastres. London.

Matsumoto J. 1999 - Taxonomic study on the genus Didymium (Physarales, Myxomycetes). Ph.D. Dissertation, University of Hiroshima, Japan.

McCormick JJ, Blomquist JC, Rusch HP. 1970 - Isolation and characteristics of an extracellular polysaccharide from Physarum polycephalum. Journal of Bacteriology 104, 1110-1118.

McHugh R, Reid C. 2008 - Aethalium cortex formation in the myxomycete Lycogala terrestre. Revista Mexicana de Micologia 27; 53-57.

McHugh R, Reid C, Ronam N. 2000 - Genesis of taenia on the capillitium of Trichiales. Mycological Research 104, 210-212.

Mims CW. 1972 - Spore wall formation in the myxomycete Arcyria cinerea. Transactions of the British Mycological Society 59, 477-481.

Mims CW, Rogers MA. 1975 - A light and electron microscopic study of stalk formation in the myxomycete Arcyria cinerea. Mycologia 67, 638-649.

Mosquera J, Lado C, Betrain-Tejera E. 2000 - Morphology and ecology of Didymium subreticulosporum. Mycologia 92, 978-982.

Nandipati SCR, Haugli K, Coucheran DH, Haskins EF, Johansen SD. 2012 - Polyphyletic origin of the genus Physarum (Physarales, Myxomycetes) revealed by nuclear rRNA minichromosome analysis and group I intron synapomorphy. BMC Evolutionary Biology 12, 166-176.

Nannenga-Bremekamp NE. 1966 - Some new species of Stemonitis, Comatricha, Badhamia, Physarum, Diderma and Didymium. Konienklijke Nederlandse Akademie van Weternschappen 69, 350-363.

Nannenga-Bremekamp NE. 1967 - Notes on myxomycetes. XII. A revision of the Stemonitales. Konienklijke Nederlandse Akademie van Weternschappen 70, 201-216. 
Nannenga-Bremekamp NE, Yamamoto Y, Sharma R. 1984 - Stemonaria, a new genus in the Stemonitaceae and two new species of Stemonitis (Myxomycetes). Konienklijke Nederlandse Akademie van Weternschappen 87, 449-469.

Nelson RK, Scheetz RW, Alexopoulos CJ. 1977 - Elemental composition of Metatrichia vesparium sporangia. Mycotaxon 5, 365-375.

Neubert H, Baumann KH. 1987 - Myxomyceten aus der Bundes-republik Deutschland IV. Schlüssel zu den Ordnungen und zu den Familien, Gattungen und Arten der Oedung Trichiales. Carolinea 45, 51-76.

Neubert H, Nowotny W, Baumann KH. 1989 - Myxomyceten aus der Bundesrepublik Deutschland IV. (Mit berûcksichtigung von vorkommen in Oberöstrreich). Carolinea 47, 25-46.

Neubert H, Nowotny W, Baumann KH. 1989 - Myxomyceten aus der Bundesrepublik Deutschland VII. (Mit berûcksichtigung von vorkommen in Oberöstrreich). Carolinea 50, 27-44.

Olive LS. 1975 - The Mycetozoans. Academic Press, New York.

Poulain M, Meyer M, Bozonnet J. 2011 - Les Myxomycètes. Fédération Mycologique et Botanique Dauphine-Savoie. Sevier, France.

Rammeloo J. 1974a - Ornamentation of the peridium inner side in the Trichiaceae (Myxomycetes), as seen with the scanning electron microscope. Bulletin de la Societe Royale de Botanique de Belgique 107, 291-304.

Rammeloo J. 1974b - Structure of the epispore in Trichiaceae (Trichiales, Myxomycetes), as seen with the scanning electron microscope. Bulletin de la Societe Royale de Botanique de Belgique 107, 353-395.

Rammeloo J. 1975 - Structure of the epispore in Stemonitales (Myxomycetes), as seen with the scanning electron microscope. Bulletin del Jardin Botanique National de Belgique 45, 301306.

Raub TJ, Aldrich HC. 1982 - Sporangia, spherules, and microcysts. In Cell Biology of Physarum and Didymium Vol II: differentiation, metabolism and methodology (eds. Aldrich HC, Daniel JW.). Academic Press, New York.

Rebhahn MA, Schnitter M, Libermann B. 1999 - Taxonomic relevance of pigment patterns in Arcyria species (Trichiales, Myxomycetes). Nova Hedwigia 69, 415-427.

Rhea RP. 1966 - Electron microscope observations of the slime mold Physarum polycephalum with specific reference to fibrillar structures. Journal of Ultrastructural Research 15, 349379.

Ross IK. 1973 - The Stemonitomycetidae, a new subclass of Myxomycetes. Mycologia 65, 477485.

Rostafinski J. 1873 - Versuch eines Systems der Mycetozoen. Inaugural-dissertation. IV. Strassburg.

Rostafinski J. 1874, 1875, 1876 - Sluzowce (Mycetozoa) Monografia. Towarzstwaa Nauk Scistych 5, 1- 215; 6, 217-243; 8 Dodatek (Appendix), 1-43.

Shadwick LL. Spiegel FW, Shadwick JDL, Brown MW, Siberman SD. $2009-$ Eumycetozoa $=$ Amoebozoa?: SSUrDNA phylogeny of protosteloid slime molds and its significance for the Amoebozoan supergroup. PLos ONE 4, e6754.

Scheetz RW, Alexopoulos CJ. 1971 - The spores of Badhamia gracilis (Myxomycetes). Transactions of the American Microscopic Society 90, 473-475.

Scheetz RW, Alexopoulos CJ. 1976 - Studies on the spores of myxomycetes. II. Physarum straminipes. Mycotaxon 4, 335-339.

Schokneckt JD. 1975 - SEM and X-ray microanalysis of calcareous deposits in myxomycete fructifications. Transactions of the American Microscopic Society 94, 21-223.

Schokneckt JD, Keller HW - 1989 Peridial calcification in the myxomycetes In Origin, evolution and modern aspects of biomineralization in plants and animals (ed. Crick RE.). Plenum Press, New York.

Schnittler M, Mitchell BW. 2000 - Species diversity in myxomycetes based on the morphological species concept - a critical examination. Stapfia 71, 55-62. 
Schnittler M, Spiegel F. 2012 - Fruit body- forming protists: Myxomycetes and Myxomycete-like organisms. In Syllabus of Plant Families, $15^{\text {th }}$ edition (ed. Frey W.).

Schnittler M, Stephenson SL, Novozhilov Y. 2000 - Ultrastructural of Barbyella minutissima Myxomycetes). Karstenia 40, 159-166.

Simon H, Henney HR. 1970 - Chemical composition of slime from three species of myxomycetes. Federation of European Biochemistry Society Letters 7, 80-82.

Spiegel FW. 1990 - Phylum plasmodial slime molds, class Protostelidia. In Handbook of Protoctista (eds. Margulis L, Corliss JO, Mellconian M, Chapman DJ.), Jones and Barlett, Boston.

Steglich W, Steffan B, Kopanski L, Eckhardt G. 1980 - Indole pigments from the fruiting bodies of the slime mold Arcyria denudata. Anglewandte Chemie 19, 459-460.

Weldon A. 1955 - Capillitial development in the myxomycetes Badhamia gracilis and Didymium iridis. Mycologia 47, 714-728.

Winsett KE, Stephenson SL. 2008 - Using ITS sequences to assess intraspecific genetic relationships among geographically separated collections of the myxomycete Didymium squamulosum. Revista Mexicana Micologia 27, 59-65.

Winsett KE, Stephenson SL. 2012 - Global distribution and molecular diversity of Didymium difforme. Mycosphere 2, 135-146.

Wrigley de Basanta d, Lado C. 2005 - A taxonomic evaluation of the stipitate Licea. Fungal Diversity 20, 261-314. 